\title{
Модернизация планировочной организации сельских поселений
}

\author{
3.К.Петрова, ЦнИИП Минстрой России, Москва
}

Статья посвящена исследованию проблемы возрождения сельских поселений, включая исследования их архитектурнопланировочной организации с применением инновационных инженерных систем. Исследования проводились на основе анализа комплекса современных социальных, природноэкологических, экономических, инженерно-технологических факторов; а также анализа отечественного и зарубежного опыта планировочной организации сельских поселений. Исследование ограничено проблематикой архитектурнопланировочной организации застройки в сельскохозяйственных поселениях с жильем для постоянного проживания людей в условиях климата умеренного пояса Центрального федерального округа России. Основная цель государственной аграрной политики состоит в формировании модели устойчивого и эффективного развития сельского хозяйства и сельских территорий в соответствии с принятой в 2019 году государственной программой «Комплексное развитие сельских территорий» на период до 2025 года. На основе анализа комплекса современных факторов, отечественного и зарубежного опыта создания сельских поселений установлена целесообразность модернизации архитектурно-планировочной организации сельских поселений с сохранением традиционных систем расселения, приёмов планировки. Для сбалансированного и равномерного развития территорий области следует создавать как крупные, так средние и мелкие сельскохозяйственные производства. В связи с этим в градостроительном планировании и развитии территорий сельских поселений автором предлагается современная структура сельских населённых пунктов: агрогород, село, деревня, хутор и пустошь. Рекомендуется в сельских поселениях применять малоэтажную преимущественно усадебную застройку с личным подсобным хозяйством, предусматривать организацию системы культурно-бытового обслуживания.

Ключевые слова: архитектурно-планировочная организация, сельские поселения, малоэтажная усадебная жилая застройка, модернизация.

\section{Modernization of the Planning Organization of Rural Settlements}

\section{Z.K.Petrova, TsNIIP Minstroy Russia, Moscow}

The article is devoted to the study of the problem of the revival of rural settlements, including the study of their architectural and planning organization with the use of innovative engineering systems. The research was carried out on the basis of an analysis of a complex of modern social, natural-ecological, economic, engineering and technological factors; as well as analysis of domestic and foreign experience in the planning organization of rural settlements. The study is limited to the problems of the architectural and planning organization of development in agricultural settlements with housing for permanent residence of people in the temperate climate of the Central Federal District of Russia. The main goal of the state agrarian policy is to form a model for sustainable and effective development of agriculture and rural areas in accordance with the state program "Integrated development of rural areas" adopted in 2019 for the period up to 2025. Based on the analysis of the complex of modern factors, domestic and foreign experience of creating rural settlements, the expediency of modernizing the architectural and planning organization of rural settlements with the preservation of traditional settlement systems, planning techniques has been established. For a balanced and even development of the region's territories, it is necessary to create both large, medium and small agricultural production. In this regard, in urban planning and development of the territories of rural settlements, the author proposes a modern structure of rural settlements: agro-town, village, village, farm and heathland. It is recommended in rural settlements to use low-rise, predominantly estate buildings with personal subsidiary plots, to provide for the organization of a system of cultural and consumer services.

Keywords: architectural and planning organization, rural settlements, low-rise manor residential buildings, modernization.

Приостановление процессов стагнации и деградации сельских населённых пунктов - одна из главных задач экологически безопасного развития сельских территорий. Сокращаются сельскохозяйственные обрабатываемые площади в нашей стране. Значительную долю сельских населённых пунктов в России составляют малые деревни - около 82,8 тыс. населённых пунктов (54\%) с числом жителей от одного до 100 человек. Наибольшее количество сельских незаселённых малых деревень обнаружено в Северо-Западном и Центральном федеральных округах. Например, в Северо-Западном федеральном округе находится пятая часть всех заброшенных деревень в России. Среди уезжающих из сельской местности лиц наблюдается большая доля молодёжи (более 58\%). 0т освоения межселённых территорий, стимулирования эконо- 
мического развития сельскохозяйственного производства и возрождения сельских населённых пунктов зависит безопасность, целостность и единство государства.

В сельских населённых пунктах мало комфортного жилья, эксплуатируются дома прошлого века. Они не оснащены или не полностью оснащены современным инженерным оборудованием. Во многих деревнях и сёлах отсутствуют объекты социального обслуживания. В сельских поселениях недостаточно развитая транспортная инфраструктура. В 45,9 тыс. (30,5\%) сельских населённых пунктов вообще отсутствуют дороги с твёрдым покрытием, которые должны обеспечивать связь с сетью дорог общего пользования региона.

Основной целью государственной аграрной политики является формирование модели устойчивого и эффективного развития сельского хозяйства и сельских территорий в соответствии с Федеральным законом «0 развитии сельского хозяйства» от 29.12.2006 N 264-Ф3 (ред. от 20.07.2018). Правительство Российской Федерации приняло в 2019 году программу «Комплексное развитие сельских территорий» на период до 2025 года включительно, разработанную Минсельхозом. Госпрограмма предусматривает реализацию мер, направленных на повышение уровня занятости сельского населения. Вместе с тем поставлены задачи создания комфортной среды для сельских жителей, в том числе развитие систем водоснабжения и водоотведения, средств связи и телекоммуникаций, увеличения уровня газификации; формирования доступности социальных услуг в сфере образования и здравоохранения, а также повышение качества дорожной инфраструктуры.

Цель проведённой автором работы состояла в исследовании архитектурно-планировочной организации сельских поселений с применением инновационных инженерных систем на основе анализа комплекса современных социальных, природно-экологических, экономических, инженернотехнологических факторов; а также анализа и обобщения отечественного и зарубежного опыта планировочной организации сельских поселений, использования инновационных инженерных технологий для улучшения качества и экологической безопасности среды жизнедеятельности сельского населения.

Исследование ограничено проблематикой архитектурно-планировочной организации застройки в сельскохозяйственных поселениях с жильём для постоянного проживания людей в условиях климата умеренного пояса Центрального федерального округа России. В исследовании использованы данные по Северо-Западному федеральному округу.

Сегодня в России наблюдается сверхконцентрация населения в столице и крупных городах. Сеть средних и малых городов слабо заселена, идет процесс депопуляции сельских поселений на обширной периферии. За последние двадцать лет в России исчезли 20 тысяч деревень - по три деревни каждый день (рис. 1). Если для стран Запада характерны процессы субурбанизации ${ }^{1}$ и контрурбанизации ${ }^{2}$, то в России они пока замедлены. Следует отметить, что еще недавно исчезновение деревень было для всей страны не так критично. Это обусловлено существованием оставшихся деревень за счёт малых городов, в которых есть кое-какая работа, а также магазины, рынки, школы, больницы и другие учреждения социально-культурного и бытового обслуживания [2]. Если начнётся исчезновение малых городов также, как и деревень, то образование обезлюденных территорий будет представлять серьёзную геополитическую угрозу для нашей страны.

Сегодня в нашей стране имеет место перекос в сторону формирования сверхкрупных землевладений. При этом формирование агрохолдингов происходит часто не за счет свободных земель, а за счёт захвата земель успешно работающих мелких предпринимателей. Именно крупные агрохолдинги получают основную долю господдержки. Выделенные на сельское хозяйство государственные субсидии до фермерских и мелких личных подсобных хозяйств не доходят. Это ведёт к ликвидации свободного класса земледельцев. При комплексном подходе к развитию сельских территорий необходимо сбалансированное соотношение крупных форм аграрных производств, бизнес-форм фермерских и мелких личных подсобных хозяйств. Опыт экономически развитых стран, таких как Канада, Скандинавские страны и Германия. свидетельствует о необходимости сбалансированного соотношения крупных аграрных производств, фермерских и мелких личных подсобных хозяйств с сохранением традиционных и исторических форм хозяйств в сельской местности [3].

Сегодня нет точных данных о количестве и принадлежности сельскохозяйственных земель. Данные Росстата, Росреестра, Росимущества и Минсельстроя существенно разнятся, так как была разрушена система изучения земель, мониторинга и картирования. Отсутствует единый орган госуправления, который отвечал бы за состояние земельных

${ }^{1}$ Субурбанизация - процесс роста и развития пригородной зоны крупных городов (производное от пригород (англ. - subarb) [1].

2 Дезурбанизация (контрурбанизация) - процесс размывания, сокращения численности городов (процесс противоположный урбанизации) [1].

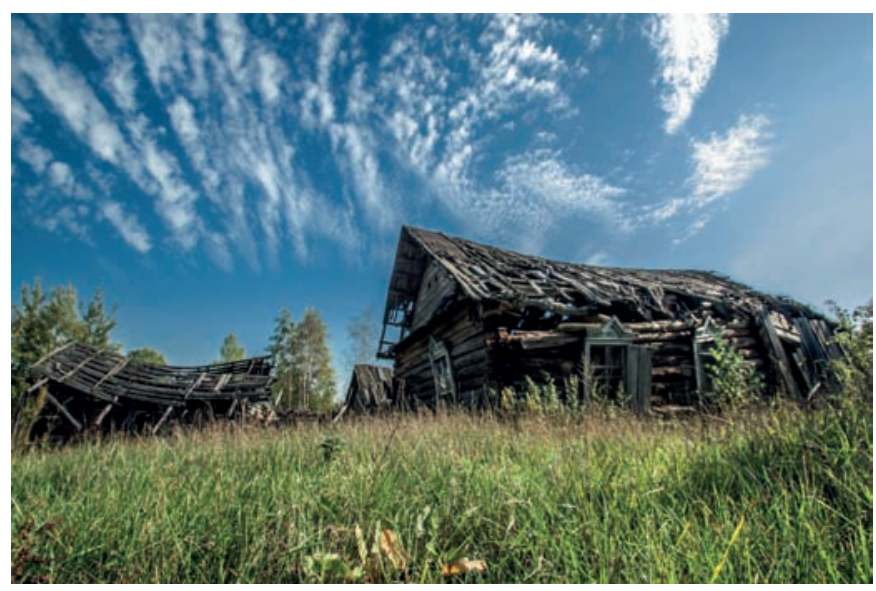

Pис. 1. Безлюдная деревня. Фото из свободного доступа сети Интернет 
ресурсов, определял их использование, охрану и принимал на себя всю полноту ответственности. В связи с указанными обстоятельствами земли не используются по назначению.

Автором установлено, что для сбалансированного и равномерного развития территорий сельских поселений необходима поддержка государством как крупных, так средних и мелких сельскохозяйственных производств. В связи с этим в градостроительном планировании и развитии территорий сельских поселений предлагается современная структура сельских населённых пунктов: агрогород, село, деревня, хутор и пустошь.

Агрогород - это город, основу функционирования которого представляют производства по выращиванию и переработке сельхозпродукции - агропромышленный комплекс (АПК). Планировочная структура базируется на идее городского пространства как специфики организации среды со всеми характерными сельскими компонентами. В государственном масштабе агрогород необходимо рассматривать как вектор развития всего АПК страны. Это связано, в первую очередь, с тем, что очень важно привлечение молодёжи для решения проблем развития сельского хозяйства. Согласно статистическим исследованиям 2/3 сельской молодёжи предпочитает жить в городе. Кроме того, так называемые вынужденные мигранты могут принять участие в строительстве агрогорода в России [4].

Жители поселений, безусловно, ценят комфорт проживания в благоустроенных коттеджах, расположенных в агрогородах, но при этом теряется самобытность, аутентичность сельской местности, привлекательность и пропадает интерес со стороны туристов. Агропромышленный комплекс накладывает большой отпечаток на традиционный облик сельской местности. Любая страна ассоциируется с определённым образом восприятия не только значимых памятников её культуры и архитектуры, но и типов сельских поселений [4].

Село - большое сельское поселение, обычно хозяйственный и административный центр для близлежащих деревень (в дореволюционной России обязательной принадлежностью такого поселения была также церковь). Деревня - небольшое крестьянское селение, один из видов населённых пунктов и адресных объектов. На начало XX века основным отличием деревни от села было отсутствие церкви в деревне и размеры поселения. Хутор - малый населённый пункт, состоящий из одного, иногда нескольких домохозяйств. Пустошь - запустевшая (от людей), заброшенная территория, на которой когда-то существовало сельское поселение. Многообразие исторических форм поселений - от мелких хуторов, небольших деревень до более крупных поселений - представляет собой совокупность равномерного воздействия человеческой деятельности на ландшафты. Типы сельских поселений России очень разнообразны. В отечественной практике применяются названные типы поселений. Они обусловлены, прежде всего, ландшафтом местности, направлением сельскохозяйственного производства, демографическими особенностями $[4 ; 5]$.
В настоящее время в центральных районах Европейской части России наиболее распространён групповой тип расселения. Это характерно также для стран Западной и Восточной Европы. Для севера России, в зоне рискованного земледелия возможно применение Финской и Норвежской моделей дисперсного (разбросанно-хуторского) расселения, в зонах климатически более благоприятных возможно использование различных моделей. В Швеции, например, отсутствует дифференциация поселений на городские и сельские.

Сельские поселения представлены следующими основными типами планировки: свободная, периметральная (центрическая), радиально-кольцевая, рядовая (линейная, уличная), регулярная, ландшафтно-усадебная и смешанная застройка (табл. 1) [6].

Рядовая или уличная застройка является наиболее распространённым приёмом сельской застройки, это результат исторического развития торговых путей. Вследствие этого появлялись и развивались селения по берегам рек и вдоль дорог. Рядовая застройка появилась вначале на берегах рек, служивших в то время летом основными водными дорогами, а зимой - санными путями. Первыми возникли поселения одной улицей вдоль берега, затем с расширением поселений стали появляться параллельные им улицы. Возникшие позже поселения вдоль грунтовых дорог развивались по тем же приёмам.

Свободная застройка - это застройка, характерная для земель с финно-угорским населением. Она является типичной для исторических малодворных селений, расположенных по берегам рек, ручьев, озер, либо в более поздний период у грунтовых дорог.

Периметральная или центрическая застройка представляет собой группировку селения вокруг какого-либо важного объекта: пруда или озера, торговой площади, водного источника и других. Такая застройка, как правило, имела круглую, овальную, прямоугольную формы.

Радиально-кольщевой приём застройки - это поселения, сформированные вокруг первичного ядра, которыми могли быть административный храм или монастырь, торговый центр, железнодорожная станция, перекрёсток дорог. Подобные типы застройки развивались далее, как радиально-кольцевая композиция. При этом наличие чётких границ препятствовало дальнейшему территориальному росту поселения.

Регулярная застройка в качестве типа планировочной организации поселений появилась позже других. Поселения с регулярной застройкой, следующей строгому плану и расположенной вдоль прямолинейных улиц, появились в XVIII веке, в связи с изданием Сенатом Указа Петра I от 7 августа 1722 года. Этим документом предписывалось строить крестьянские дворы и поселения, а также ремесленные слободы только согласно чертежу. Если рядовая застройка была удобной, учитывала естественные изгибы рельефа и в ней проявлялась вековая мудрость русского народа, то регулярная застройка всё это перечёркивала своей регулярностью [7]. 
Таблица 1. Типы архитектурно-планировочной организации сельских населённых пунктов Европейской части России [7]

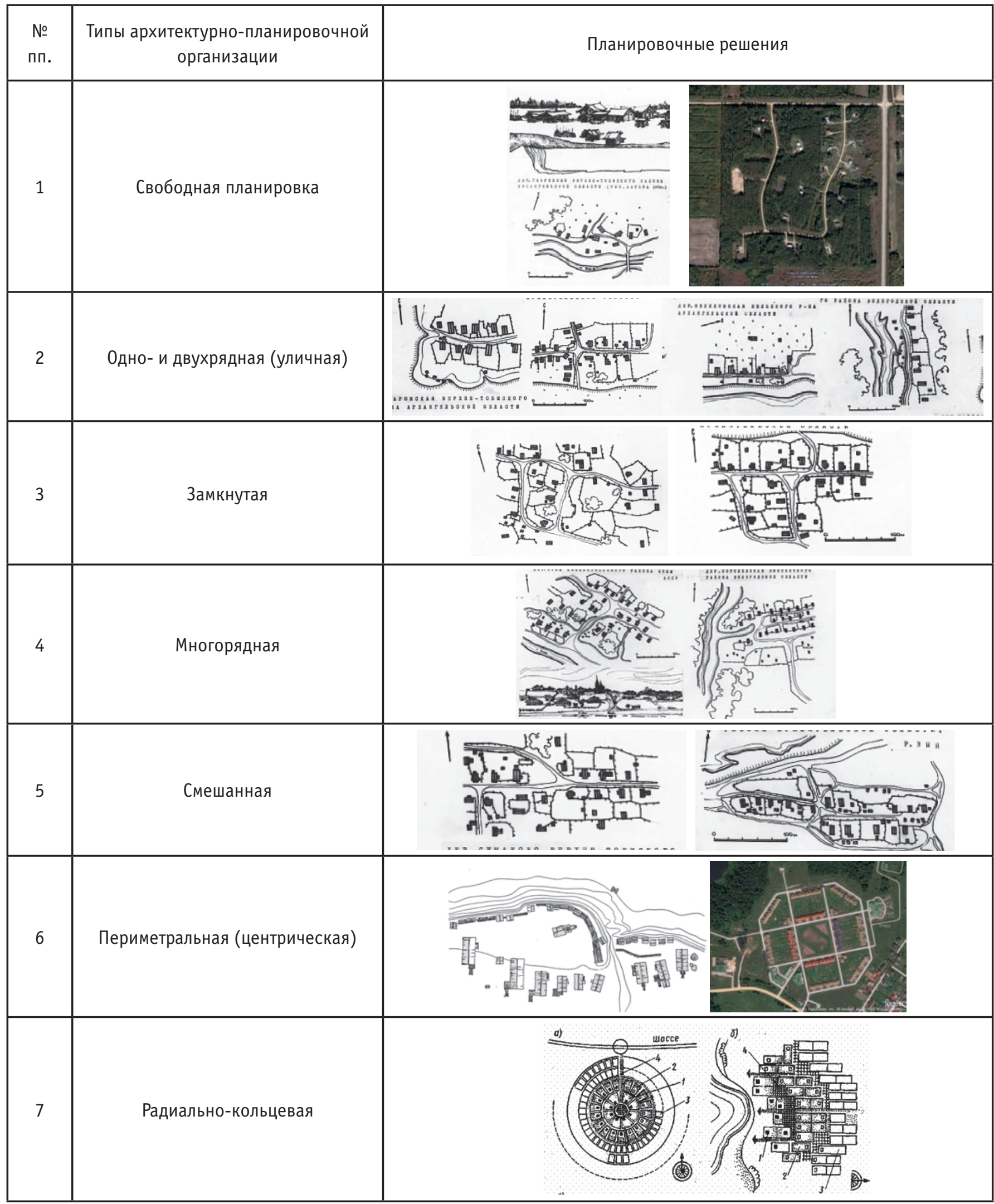


Продолжение таблицы 1.

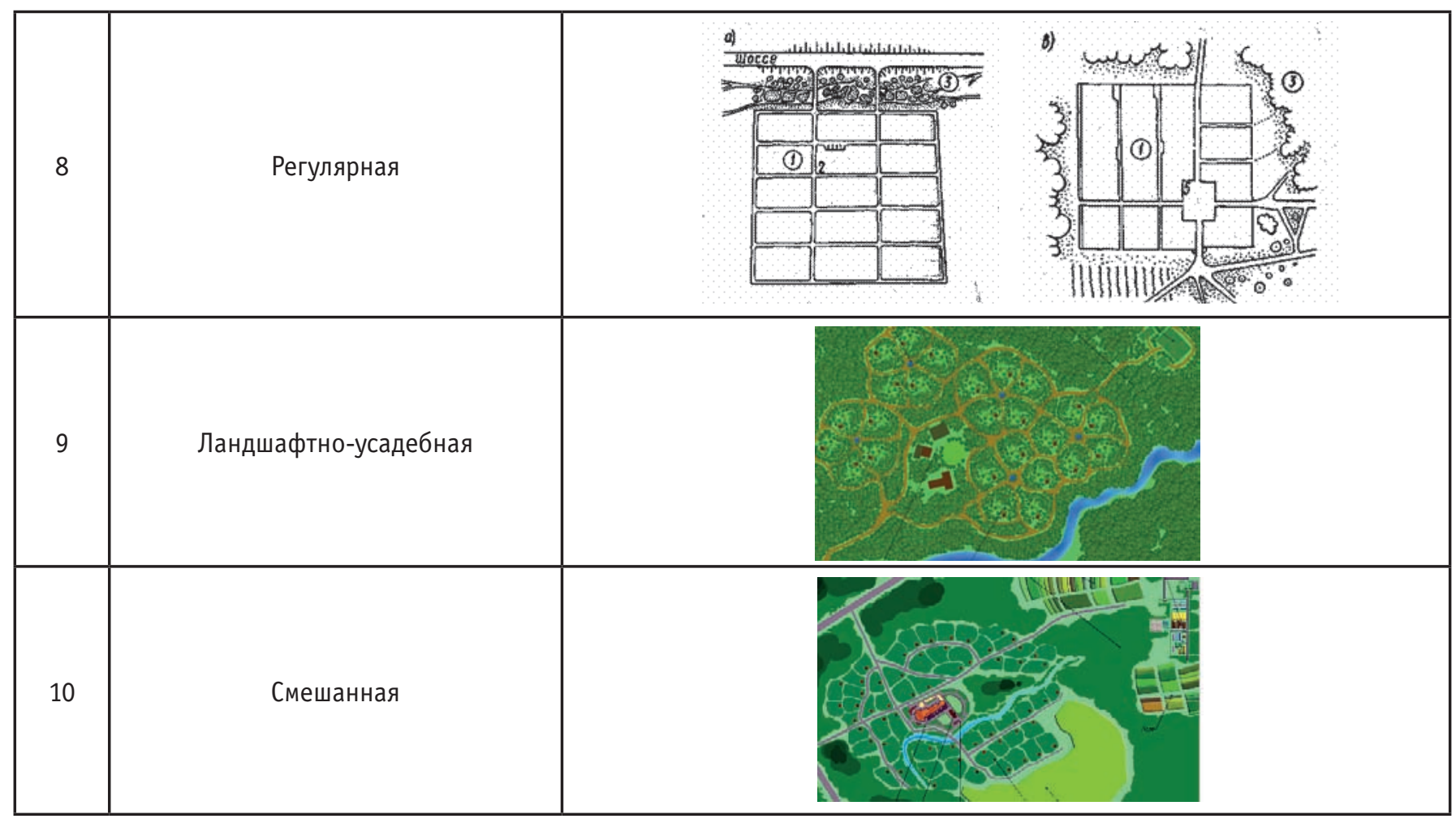

Целесообразность регулярной застройки была только при строительстве заводских слобод и рабочих посёлков. Новые посёлки строились по разработанному плану, с прямолинейной планировкой улиц однотипными участками. Преимущества регулярной застройки проявились, когда одиночные усадьбы стали заменять каменными двух- и трёхэтажными домами.

В современной планировке сёл регулярная застройка применяется, как правило, в больших и крупных сёлах (свыше 1000 человек). Планировка таких сёл бывает также комбинированной, то есть как сочетание, например, регулярной и радиально-кольцевой.

Ландшафтно-усадебная застройка - это новый перспективный способ заселения территорий с учётом комплекса взаимосвязанных условий комфортного, экологичного и экономически самодостаточного проживания населения в поселениях нового типа. Такие поселения должны соответствовать следующим основным требованиям [7]: максимальный размер (диаметр) поселения не должен превышать 5-6 км; обеспечивается экологическая безопасность окружающей среды; архитектура поселений должна быть гармонично вписана в природный ландшафт местности; следует применять автономные энергоэффективные технологии при строительстве и эксплуатации жилых, административных и производственных зданий и сооружений.

В связи с политикой укрупнения хозяйств, проводимой в середине прошлого века, получили развитие многорядный и радиально-кольцевой планировочные типы поселений. На пересечении сухопутных трасс, дорог местного и внутреннего значения формируется радиально-кольцевая планировка поселения. Её достоинством является хорошая доступность центра с необходимыми для поселения объектами социальной инфраструктуры. Радиально-кольцевая планировка поселений также имеет достаточную возможность пространственного расширения.

Многорядная планировка и регулярная с прямоугольной сеткой улиц получили развитие благодаря рациональной организации транспортного движения и разрастания территории поселения с увеличением населения. Такая планировка характерна для крупных поселений. Она недостаточно приспособлена к условиям сельской местности, ландшафту, включая пластику рельефа [7].

Планировка и дендрологический состав зелёных насаждений должны обеспечивать экологическую безопасность всех функциональных зон поселения - жилой, общественной, производственной. Для этого эти зоны необходимо разделять защитными полосами или пространствами в виде парков, скверов, лесопарков. Автомобильные дороги как потенциальный источник различных шумов и пыли обсаживаются полосами деревьев и кустарников.

Так, в Медынском районе в поселке Новые Лужки, который входит в состав агрохолдинга «Мосмедыньагропром», замкнутость пространства территории рассматриваемого поселения не способствует раскрытию ландшафтных ви- 
дов на прилегающие территории (рис. 2). Планировочная организация посёлка, включающего 99 жилых единиц, не соответствует сельскому поселению и больше характерна для рабочего посёлка. Двухквартирные блок-дома в блокированной застройке имеют небольшие земельные участки, не предназначенные для ведения подсобного хозяйства.

План поселения имеет регулярную ячеистую структуру с ярко выраженным центром, транспортные дороги не пересекают этот центр, а обходят его. Центр посёлка занимает достаточно большую площадь и имеет неинтересный вид на ровный газон, окружающий детскую площадку. Озеленение, представленное несколькими туями, достаточно бедное (рис. 3).

В рассматриваемом примере ограничение внутрипоселкового движения автомобильного транспорта для создания в центре пешеходной зоны не осуществимо. Это обусловлено необходимостью подъезда к собственным домам, которые имеют гаражи (см. рис. 2). При этом транспортное движение осуществляется практически по круговой, что создаёт определённые трудности для пешеходов.

Планировку сельского поселения не следует уподоблять городской. Из-за этого большинство современных сельских планировок обладает громадными недостатками. При развитии и расширении агрохолдингов будут построены ещё новые поселения, подобные Новым Лужкам, максимально близко расположены к местам приложения труда. Агрохолдинги не заинтересованы в развитии традиционных типов сельских поселений. Территориальное развитие сельских поселений России при доминировании агрохолдингов к концу XXI века будет представлять собой ячеистую мозаику, состоящую из комфортных, небольших поселений с однотипной планировочной структурой. Этот тип поселений рассчитан на проживания в них работников агрохоллдингов. Такую направленность, практически разработанную, можно видеть в современных европейских проектах (рис. 4).

Традиционный тип сельского жилья - усадебный однодвухэтажный жилой дом с прилегающим земельным участком. В сельской местности имеются три типа усадебного жилья: для сельского жителя, фермера, второе жилище горожанина (рис. 5).

Для сохранения психического и физического здоровья семьи, состоящей из трёх-четырёх человек и проживающей в малоэтажном жилом доме, формирования на приусадебном участке устойчивого и продуктивного биоценоза, находящегося в экологическом равновесии, и самообеспечения продуктами питания необходимо иметь земельный участок площадью не менее одного гектара.

При проектировании сельских поселений следует учитывать близость жителей к земле, связь с природным ландшафтом, применение малоэтажной преимущественно усадебной застройки; наличие личного подсобного хозяйства, наличие мест приложения труда не только в населённом пункте, но и далеко за его пределами. При этом необходима организация ступенчатой системы культурно-бытового обслуживания с размещением ступеней периодического и эпизодического обслуживания далеко за пределами конкретного поселения, создание культурного ландшафта, возрождение и сохранение историко-культурного наследия (при его наличии), а также создание дорог с твёрдым покрытием и развитие транс-

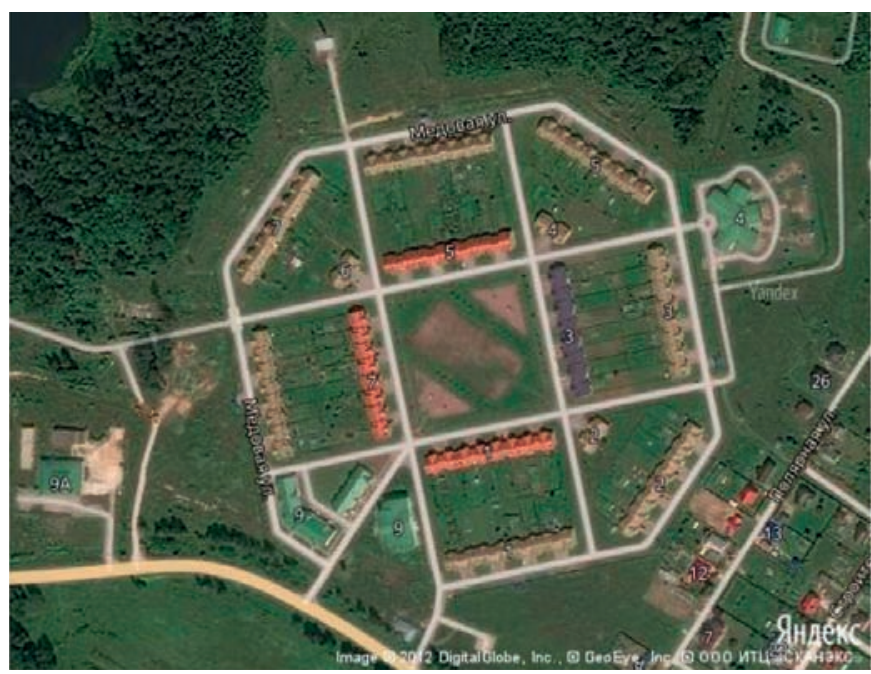

Рис. 2. Генплан посёлка Новые Лужки. Медынский район Московской области. Фото из свободного доступа сети Интернет

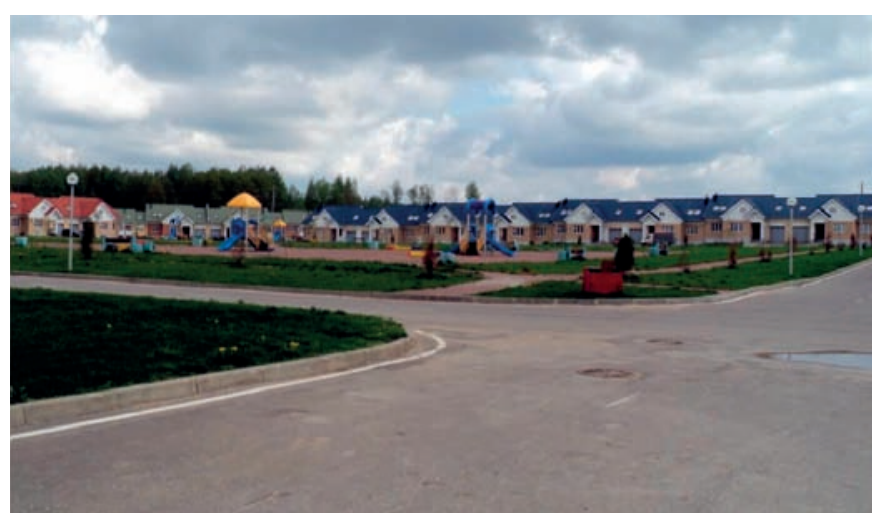

Рис. 3. Посёлок Новые Лужки. Медынский район Московской области. Вид на застройку. Фото 3.К. Петровой

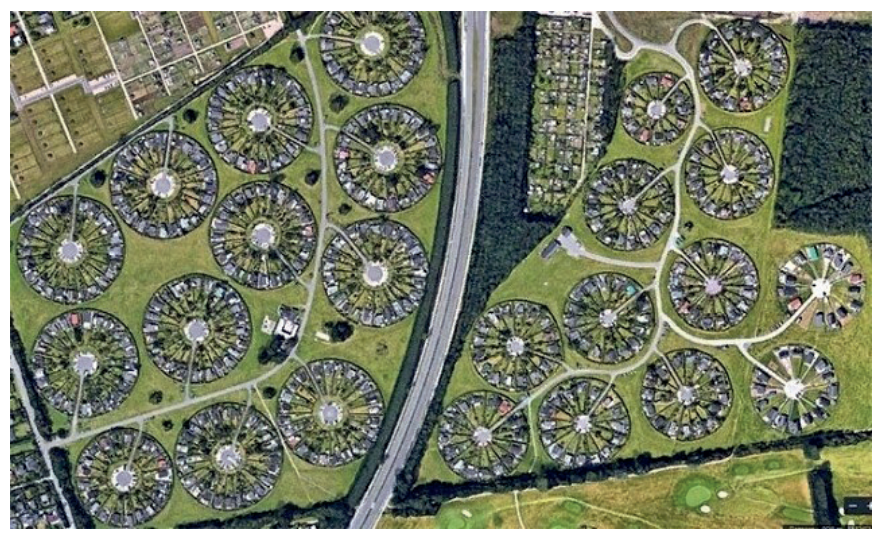

Рис. 4. Экопоселения будущего. Фото из свободного доступа сети Интернет 
портного обслуживания. Важную роль играет обеспечение инновационной инженерной инфраструктурой (автономной, локальной и централизованной) и другие специфические особенности условий сельских территорий (рис. 6).

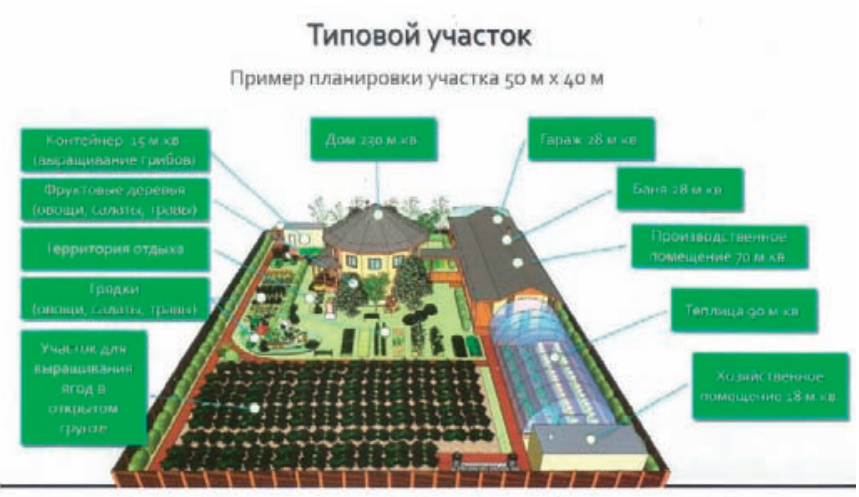

Pис. 5. Модель типового усадебного участка (неразвитого типа) как второго жилище горожанина, площадью 20 соток (автор - к.т.н., академик МАНЭБ В.А. Морозов)

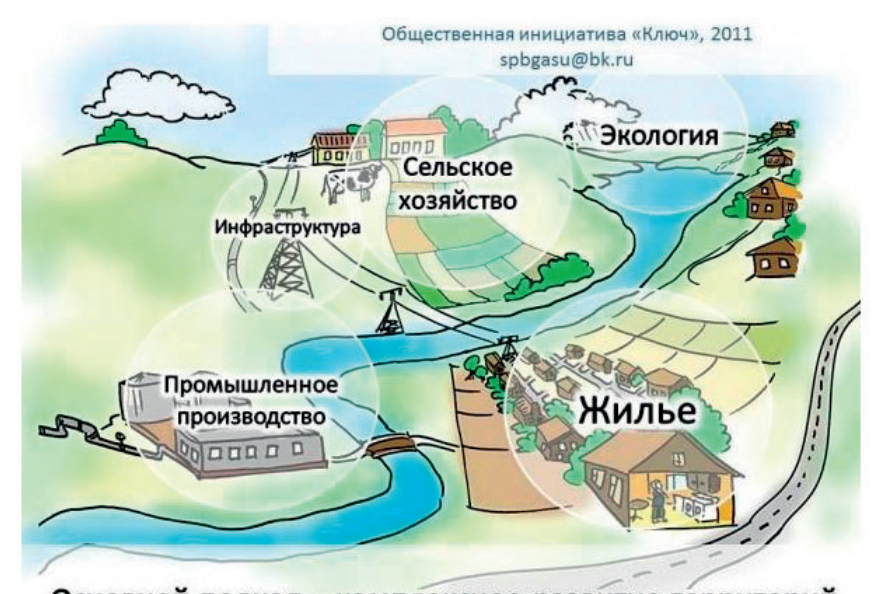

Основной подход - комплексное развитие территорий

Рис. 6. Модель комплексного развития территорий (источник: http://refleader.ru/jgernapolmerqas.html)

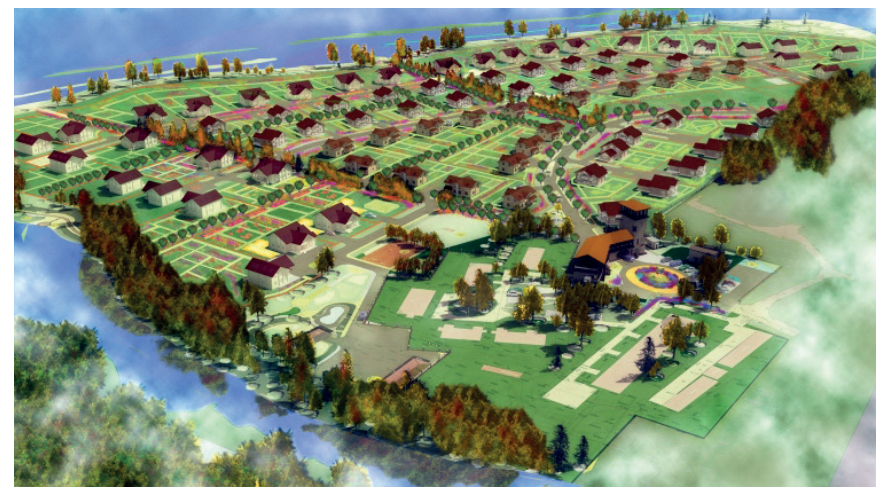

Рис. 7. Архитектурно-планировочная концепция озеленения территории экопоселения «Полуостров» на берегу Истринского водохранилища. Московская область, 47-й километр Пятницкого шоссе. Ландшафт в эко-стиле. Студия Алексея Иванова «Архстройдизайн АСД» (источник: https://i.archi. ru/i/752_418/117188.jpg)
В модели комплексного развития территорий, предложенной в работе 2011 года «Разработка жизнеспособной модели сельских поселений XXI века» ${ }^{3}$ не учтены такие элементы формирования современной модели комплексного развития сельского поселения, как организация ступенчатой системы культурно-бытового обслуживания, создание культурного ландшафта, возрождение и сохранение историко-культурного наследия (при его наличие), создание дорог с твердым покрытием и развитие транспортного обслуживания, обеспечение инновационной инженерной инфраструктурой. Дополненная модель комплексного развития сельского поселения образует современную планировочную структуру сельского поселения.

Пример современной планировочной структуры сельского поселения с ландшафтом в эко-стиле представлен на рисунке 7. Важным элементом проектного решения является система озеленённых пространств и организация улично-дорожной сети, пронизывающей элементы планировочной структуры планируемой территории ${ }^{3}$.

\section{Выводы}

1. На основе анализа комплекса современных социальных, природно-экологических и экономических факторов, отечественного и зарубежного опыта создания сельских поселений установлена целесообразность модернизации архитектурнопланировочной организации сельских поселений с сохранением традиционных систем расселения и приёмов планировки в соответствии с влиянием вышеназванных факторов.

2. От уровня экономического освоения территории, плотности населения и обустройства сельской местности в значительной степени зависят безопасность, целостность и единство государства. Необходимо приблизить уровень жизни сельского населения к уровню жизни населения крупных городов за счёт создания мест приложения труда, увеличения зарплат сельских жителей до уровня зарплат горожан.

3. Для сбалансированного и равномерного развития территорий следует создавать условия как для крупных, так средних и мелких сельскохозяйственных производств. В связи с этим в градостроительном планировании и развитии территорий сельских поселений автором предлагается современная структура сельских населённых пунктов: агрогород, село, деревня, хутор и пустошь.

4. В сельских населённых пунктах должны быть созданы условия для осуществления важнейших производственных, жилищных, социально-культурных функций населения, развития их интеллектуального и творческого потенциала, физкультуры и спорта, сохранения историко-культурных традиций в планировке и архитектуре зданий, возрождения народных промыслов и развития туризма. Осуществление этих функций в первую очередь зависит от строительства дорог с твердым покрытием и развития транспортного обслуживания.

${ }^{3}$ Отчёт по теме «Разработка жизнеспособной модели сельских поселений XXI века» (http://refleader.ru/jgernapolmerqas.html). 
5. Проектирование сельских поселений следует осуществлять на основе применения малоэтажной преимущественно усадебной застройки с личным подсобным хозяйством или без него. Необходима организация ступенчатой системы культурно-бытового обслуживания с размещением ступеней периодического и эпизодического обслуживания далеко за пределами конкретного поселения. Следует предусматривать создание культурного ландшафта в поселении (парков, скверов, аллей).

\section{Лumepamypa}

1. Постиндустриальная эпоха урбанизации [Электронный ресурс] // HELPIKS.ORG. - Режим доступа: https://helpiks. org/6-77504.html (дата обращения 11.10.2020).

2. Россия - страна умирающих деревень [Электронный ресурс] // Центр экономических и политических реформ. Официальный сайт. - Режим доступа : cepr.su>wp-content...2016/12/ Россия...деревень (дата обращения 06.01.2017).

3. ЕС тратит треть годового бюджета на поддержку агросектора [Электронный ресурс] // Ведомости - Режим доступа: https://www.vedomosti.ru/business/articles/2013/03/19/ deshevo (дата обращения 06.01.2017).

4. Петрова, 3.К. Как возродить сельские поселения в России? / 3.К. Петрова, В.О. Долгова // Градостроительство. - 2019. - № 1. - С. 29-36.

5. Петрова, 3.К. Процесс возрождения сельских поселений и культурный ландшафт / 3.К. Петрова, В.0. Долгова // Academia. Архитектура и строительство. - 2019. - № 1. - С. 70-77.

6. Петрова, 3.К. Влияние социальных, природно-экологических, экономических, инженерно-технологических и историко-культурных факторов на планировочную организацию сельских поселений / 3.К. Петрова // Материалы международной научно-практической конференции «Наука, образование и экспериментальное проектирование». 2-6 апреля 2018 г. - М. : МАРХИ, 2020. - С. 102-106.

\section{References}

1. Postindustrial'naya epokha urbanizatsii [Postindustrial era of urbanization]. HELPIKS.ORG. Website. - Access mode: https:// helpiks.org/6-77504.html (Accessed 10/11/2020). (In Russ.)

2. Rossiya - strana umirayushchikh dereven' [Russia - the country of dying villages]. Tsentr ekonomicheskikh i politicheskikh reform. Ofitsial'nyi sait [Center for Economic and Political Reforms. Official site]. Access mode: cepr.su>wp-content...2016/12/ Rossiya...dereven' (Accessed 01/06/2017). (In Russ.)

3. ES tratit tret' godovogo byudzheta na podderzhku agrosektora [The EU spends a third of the annual budget to support the agricultural sector]. Vedomosti. Access mode: https://www.vedomosti.ru/business/articles/2013/03/19/ deshevo (Accessed 01/06/2017). (In Russ.)

4. Petrova Z.K., Dolgova V.0. Kak vozrodit' sel'skie poseleniya $\checkmark$ Rossii? [How to revive rural settlements in Russia?]. In: Gradostroitel'stvo [Urban planning], 2019, no. 1, pp. 29-36. (In Russ., abstr.in Engl.)

5. Petrova Z.K., Dolgova V.0. Protsess vozrozhdeniya sel'skikh poselenii i kul'turnyilandshaft [The process of the revival of rural settlements and the cultural landscape]. In: Academia. Arkhitektura i stroitel'stvo [Academia. Architecture and construction], 2019, no. 1, pp. 70-77. (In Russ., abstr.in Engl.)

6. PetrovaZ.K. Vliyanie sotsial'nykh, prirodno-ekologicheskikh, ekonomicheskikh, inzhenerno-tekhnologicheskikh i istorikokul'turnykh faktorov na planirovochnuyu organizatsiyu sel'skikh poselenii [The influence of social, natural-ecological, economic, engineering-technological and historical-cultural factors on the planning organization of rural settlements]. In: Materialy mezhdunarodnoi nauchno-prakticheskoi konferentsii «Nauka, obrazovanie $i$ eksperimental'noe proektirovanie» [Materials of the International Scientific and Practical Conference "Science, Education and Experimental Design"]. April 2-6, 2018. Moscow, MARKh Publ., 2020, pp. 102-106. (In Russ.)

Петрова Зоя Кирилловна (Москва). Доктор архитектуры, советник РААСН. Главный научный сотрудник отдела «Территориальные основы градостроительства» ФГБУ «ЦНИИП Минстроя России» (119331, Москва, просп. Вернадского, 29. ЦНИИП Минстроя России). Эл.почта: petrovaz777@mail.ru.

Petrova Zoya K. (Moscow). Doctor of Architecture, Advisor of RAACS. Chief Researcher at the Department of Territorial Foundations of Urban Development at the the Institute for Research and Design of the Ministry of Construction and Housing and Communal Services of Russia (29 Vernadskogo avenue, Moscow, 119331. TsNIIP). E-mail: pttrovaz777@mail.ru. 